\title{
Tingkat keberhasilan Inseminasi Buatan (IB) menggunakan semen beku hasil sexing pada Sapi Persilangan Ongole
}

\section{The success rate of Artificial Insemination (IB) using frozen sexing semen from on ongole crossbred}

\author{
Ali Mahfud, Nurul Isnaini, Trinil Susilawati, Aulia Puspita Anugra Yekti, Kuswati* \\ Program Studi Magister Ilmu Ternak, Fakultas Peternakan Universitas Brawijaya \\ Jl. Veteran, Malang (65145)
}

Submitted: 21 Mei 2019, Accepted: 7 Agustus 2019

\begin{abstract}
ABSTRAK: Inseminasi buatan (IB) menggunakan semen sexing bertujuan untuk mendapatkan pedat dengan jenis kelamin sesuai harapan. Tujuan penelitian ini bertujuan untuk mengetahui keberhasil IB semen beku non sexing dan sexing. Materi dalam penelitian menggunakan 77 ekor akseptor IB non sexing dan 77 ekor akseptor IB sexing yang di IB secara double dosis. Metode penelitian ini menggunakan eksperimental dengan percobaan lapang (field experiment) dengan perlakuan penelitian adalah $\mathrm{P} 0=$ straw semen beku non sexing dan $\mathrm{P} 1$ = straw semen beku spermatozoa $\mathrm{Y}$ hasil sexing dengan metode pemisahan Sentrifugasi Gradien Densitas Percoll (SGDP) yang diproduksi oleh Balai Besar Inseminasi Buatan (BBIB) Singosari. Variabel penelitian meliputi Non Return Rate (NRR), Service Per Conception (S/C) dan Conception Rate (CR). Data yang diperoleh dianalisis secara deskriptif. Hasil penelitian pada masing - masing perlakuan IB non sexing dan sexing secara berturut - turut yaitu persentase nilai NRR 1 sebesar 90,91\% dan 77,92\%, nilai NRR 2 sebesar 88,31\% dan $76,62 \%$, persentase kebuntingan sebesar $84,42 \%$ dan 75,33\%, nilai CR sebesar 79,22 \% dan 57,14 $\%$. Kesimpulan penelitian bahwa IB menggunakan semen beku non sexing memiliki tingkat keberhasilan yang lebih tinggi dibandingkan dengan IB menggunakan semen beku hasil sexing.
\end{abstract}

Kata kunci: Inseminasi buatan; kebuntingan; double dosis.

ABSTRACT: The purpose of artificial insemination using sexing semen was to obtain the calf according to the expected sex. This study aimed to determine the success of artificial insemination in non-sexing and sexing of frozen semen. The materials used in this research were 77 non-sexing artificial insemination acceptor cows and 77 sexing artificial insemination acceptor cows with double dose treatment. The method used in this study was experimental field experiment with the research treatment: $\mathrm{P} 0=$ frozen non-sexing semen straw and P1 = frozen semen of spermatozoa $\mathrm{Y}$ by sexing method using Percoll Density Gradient Centrifugation (SGDP) produced by Balai Besar Inseminasi Buatan (BBIB) Singosari. The variables of this study were Non Return Rate (NRR), Service Per Conception (S/C) and Conception Rate (CR). The data obtained were analyzed descriptively. The results of the study in each non-sexing and sexing artificial insemination treatment were: the percentage of NRR 1 were $90.91 \%$ and $77.92 \%$, followed by NRR 2 with $88.31 \%$ and $76.62 \%$, the pregnancy percentage were $84.42 \%$ and $75.33 \%$, and the CR values were $79.22 \%$ and $57.14 \%$. The conclusion of this study was artificial insemination using frozen non-sexing semen had a higher success rate compared to artificial insemination using frozen sexing semen.

Keywords: Artificial insemination; pregnancy; double doses.

*Corresponding Author: kuswati_indicus@ub.ac.id

DOI: 10.21776/ub.jiip.2019.029.02.10 


\section{PENDAHULUAN}

Penentuan jenis kelamin memiliki keunggulan antara lain dapat mengurangi biaya manajemen pemeliharaan, dapat mengatur rasio jenis kelaimin sampai 90 : 10, mengurangi biaya dalam program progeni test dan embrio transfer (Bhalakiya, et. al., 2018). Spermatozoa yang mengandung kromosom $\mathrm{Y}$ dan $\mathrm{X}$ memiliki beberapa perbedaan seperti, ukuran spermatozoa Y lebih kecil, spermatozoa $\mathrm{Y}$ mengandung DNA yang lebih sedikit sehingga pergerakannya cepat dan spermatozoa $\mathrm{Y}$ mengandung $\mathrm{H}-\mathrm{Y}$ antigen (Boro, et. al., 2016). Spermatozoa $\mathrm{X}$ yang lebih berat akan mengendap dibagian bawah, sedangkan spermatozoa $\mathrm{Y}$ yang lebih ringan akan bermigrasi ke bagian atas (Kanesharatnam, Eswaramohan and Balasubramaniam, 2012).

Teknik pemisahan spermatozoa didasarkan pada kecepatan gerak spermatozoa yang diberi pada sebuah gradien (Hafez and Hafez, 2008). Metode pemisah menggunakan sentrifugasi gradien densitas percoll lebih baik dan dapat dibuat dengan mudah jika dibandingkan dengan metode lain (Susilawati, 2014), (Susilawati et al 2014) karena percoll adalah medium yang terdiri dari partikel koloid yang diselimuti dengan polyvunyphyrrolidone (PVP) yang mampu meningkatkan motilitas spermatozoa. Hasil pemisahan dengan metode sentrifugasi gradien densitas percoll dengan kecepatan 2250 rpm selama 5 menit menghasilkan rasio spermatozoa sebesar $83,1 \%$ dengan penurunan motilitas $10 \%$ berdasarkan identifikasi ukuran kepala spermatozoa (Susilawati, 2014). Hasil penelitian dengan metode yang sama oleh Kusumawati et al (2017) motilitas semen non sexing dan sexing (sperma Y) before freezing adalah $64,25 \pm 3,94 \%$ dan 53,7 $\pm 7,93 \%$, Hasil penelitian Yekti et al (2018) Hasil IB menggunakan semen cair hasil sexing menggunakan metode yang sama yaitu sentrifugasi gradien densitas percoll, pada pengencer $\mathrm{CEP} 3+$ kuning telur dan pengencer Tris aminomethan kuning telur menghasilkan Conception Rate 66,7 \% dan $62,2 \%$.

Hasil penelitian Setiyani dkk (2018) menyatakan bahwa nilai Conception Rate hasil IB single dosis menggunakan semen beku non sexing dan semen beku dengan metode sexing SGDP adalah $35,48 \%$ dan $43,47 \%$ dan hasil penelitian Susilawati (2005) bahwa ketepatan jenis kelamin pedet jantan Inseminasi Buatan (IB) menggunakan semen beku non sexing sebesar $50 \%$, sedangkan semen sexing spermatozoa Y sebesar $75 \%$.

Berdasarkan hal tersebut penelitian ini bertujuan untuk mengetahui tingkat keberhasilan IB semen beku non sexing dan semen beku hasil pemisahan (sexing) pada sapi persilangan ongole berdasarkan persentase Non Return Rate (NRR), persentase Kebuntingan dan Conception Rate (CR).

\section{MATERI DAN METODE Lokasi dan waktu penelitian}

Penelitan ini dilakukan pada tanggal 28 Juli - 15 Oktober 2018. Uji kualitas spermatozoa Post Thawing Motility (PTM) dilakukan di Labolatorium Reproduksi Fakultas Peternakan Universitas Brawijaya, Malang dan Inseminasi Buatan (IB) dilakukan di 6 Desa yaitu Desa Leran Kulon, Desa Leran Wetan, Desa Wangun, Desa Cepokorejo, Desa Ketambul dan Desa Glodog, Kecamatan Palang Kabupaten Tuban, Jawa Timur.

\section{Materi dan metode penelitian}

Materi yang digunakan dalam penelitian ini adalah 77 ekor sapi persilangan ongole calon akseptor IB semen beku non sexing dan 77 ekor sapi sapi persilangan ongol calon akseptor IB semen beku sexing dengan kriteria body condition score $(\mathrm{BCS})>4$, tidak ada gangguan reproduksi dan memiliki kualitas berahi minimal vulva merah, bengkak dan hangat (3A). Semen beku non sexing dan sexing sapi Limousin yang diproduksi oleh Balai Besar Inseminsai Buatan (BBIB) Singosari, Malang. Semen 
beku sexing dipisahkan menggunakan metode Sentrifugasi Gradien Densitas Percoll (SGDP). Penelitian ini menggunakan metode eksperimental di lapang (field experiment) dengan perlakuan $\mathrm{P} 0=$ straw semen beku non sexing dan $\mathrm{P} 1=$ straw semen beku spermatozoa $\mathrm{Y}$ hasil sexing dengan metode pemisahan Sentrifugasi Gradien Densitas Percoll (SGDP), Teknik IB dilakukan dengan metode deep insemination menurut, Susilawati (2011) bahwa metode tersebut dilakukan pada posisi 4+. IB dilakukan dengan double dosis.

\section{Variabel pendukung}

Variabel pendukung dalam penelitian ini meliputi:

1. Uji kualitas spermatozoa Post Thawing Motility (PTM)

2. Kecukupan kebutuhan nutrisi pakan di lokasi penelitian

\section{Variabel pengamatan}

Variabel yang diamati meliputi:

1. Non Return Rate (NRR) yaitu persentase banyaknya akseptor IB yang tidak menunjukkan tanda - tanda berahi di hari ke- 18-21 pasca IB (NRR 1) dan hari ke- 40-42 pasca IB (NRR 2) (Susilawati, 2011).

2. Persentase kebuntingan yaitu persentase banyaknya sapi akseptor IB yang bunting pasca dilakukan pemeriksaan kebuntingan menggunakan metode palpasi rektal (Susilawati, 2011).

3. Conception Rate (CR) yaitu persentase angka kebuntingan dilihat dari banyaknya akseptor IB yang bunting pada IB pertama melalui palpasi rektal (Susilawati, 2011).

\section{Analisis Data}

Data yang diperoleh dari masingmasing variabel pengamatan ditabulasi dan diolah menggunakan Microsoft Excel untuk mencari nilai rata-rata. Hasil data yang sudah diolah dilanjutkan dengan analisis deskriptif (Harsojuwono, Arnata dan Puspawati, 2011).

\section{HASIL DAN PEMBAHASAN}

Hasil uji semen beku yang digunakan pada penelitian ini memiliki kualitas Post Thawing Motility (PTM) pada P0 (semen beku non sexing) $36,00 \pm 1,00 \%$ sedangkan P1 (semen beku sexing) 31,40 $\pm 1,84 \%$, Hasil penelitian Susilawati et al, (2014) dengan menggunakan metode yang sama PTM pada semen beku sexing 36,5 \pm $13,13 \%$. Hasil penelitian program IB menggunakan semen beku non sexing dan sexing pada peternakan rakyat dapat dilihat pada Tabel 1.

Tabel 1. Tingkat Keberhasilan IB

\begin{tabular}{cccccccccc}
\hline Perlakuan & Total & \multicolumn{2}{c}{ (NRR) } & \multicolumn{2}{c}{ (NRR) 2} & \multicolumn{2}{c}{$\begin{array}{c}\text { Persentase } \\
\text { Kebuntingan }\end{array}$} & \multicolumn{2}{c}{ (CR) } \\
\cline { 3 - 10 } $\begin{array}{c}\text { IB Semen } \\
\text { Beku }\end{array}$ & $\begin{array}{c}\text { Akseptor IB } \\
\text { (Ekor) }\end{array}$ & $\mathrm{Bt}$ & $\operatorname{Pr}(\%)$ & $\mathrm{Bt}$ & $\operatorname{Pr}(\%)$ & $\mathrm{Bt}$ & $\operatorname{Pr}(\%)$ & $\mathrm{Bt}$ & $\operatorname{Pr}(\%)$ \\
\hline P0 & 77 & 70 & 90,91 & 68 & 88,31 & 65 & 84,42 & 61 & 79,22 \\
P1 & 77 & 60 & 77,92 & 59 & 76,62 & 58 & 75,32 & 44 & 57,14 \\
\hline
\end{tabular}

Keterangan: $\quad$ P0 $=$ Perlakuan Non Sexing, P1 = Perlakuan Sexing; NRR: Non Return Rate; CR: Conception Rate; Bt: Bunting (ekor); Pr: Persentase (\%)

\section{Non Return Rate (NRR)}

Non Return Rate (NRR) adalah salah satu metode pendugaan kebuntingan pada induk akseptor IB pasca IB. Menurut, Varotto, et al (2016) berpendapat bahwa non return rate (NRR) merupakan salah satu indikator kesuburan ternak dan evaluasi kinerja reproduksi tanpa menunggu partus. Berdasarkan Tabel 1. Menunjukkan bahwa pada hasil pengamatan NRR 1 ke NRR 2 terjadi penurunan persentase kebuntingan akibat kenaikan jumlah akseptor IB yang berahi. Hasil pendugaan kebuntingan dari program 
IB semen beku non sexing dan sexing dengan metode NRR 2 sebesar 88,31\% dan 76,62\% yakni 68 ekor dan 59 ekor. Salah satu penyebab terjadinya berahi ulang pasca IB adalah kematian embrio sebelum implantasi atau hipofungsi ovary (Yekti et al, 2018).

Munculnya berahi ulang pasca IB ditunjukkan dengan gejala - gejala seperti intensitas bersuara tinggi, vulva bengkak dan agak mengkilat, berlendir, induk gelisah dan jika didekati akan diam serta sebagian induk terjadi penurunan nafsu makan dan minum. Salah satu penyebab terjadinya berahi ulang pasca IB adalah kematian embrio sebelum implantasi. Implantasi merupakan menempelnya embrio pada endomtrium. Menurut, Widayati, dkk (2013) menyatakan bahwa kesiapan endometrium dalam menerima embrio dini ditandai dengan perubahan yang terjadi pada permukaan endometrium, yaitu lapisan sel yang terluar berubah berupa pinopodes yang memudahkan embrio kontak dengan endometrium. Perubahan endometrium tersebut melibatkan beberapa hal, diantaranya mulai peranan hormon steroid yang dihasilkan oleh ovarium maternal, estrogen, progesteron, autokrin, parakrin, molekul adhesi dan sitokin - sitokin.

\section{Persentase Kebuntingan}

Berdasarkan Tabel 1. bahwa dari total 77 ekor setiap perlakuan menunjukkan bahwa program IB menggunakan semen beku sexing mempunyai persentase kebuntingan yang lebih rendah di bandingkan dengan IB menggunakan semen beku non sexing. Persentase kebuntingan tersebut masing - masing perlakuan yaitu non sexing sebesar 84,42 $\%$ dan sexing sebesar $75,32 \%$. Tetapi hasil penelitian ini lebih baik dari penelitian Gunawan, Kaiin dan Said (2015) bahwa nilai kebuntingan IB menggunakan semen beku non sexing sebesar 80,67\% dan sexing 68,29\%.

Rendahnya persentase kebuntingan IB dengan semen beku sexing tersebut diduga karena rendahnya kualitas spermatozoa akibat rusaknya membran sel spermatozoa selama proses pemisahan (sexing). Hal ini sesuai dengan pendapat Sianturi, dkk. (2004) bahwa akibat proses sentrifugasi selama pemisahan akan menurunkan kualtas mencapai 20\%. Menurut Arifiantini, dkk (2010) bahwa salah satu faktor yang mempengaruhi persentase kebuntingan dan CR hasil IB semen beku adalah rendahnya jumlah spermatozoa motil.

Penyimpanan semen dalam bentuk beku dimungkinkan salah satu faktor yang mempengaruhi kualitas spermatozoa. Hal ini sesuai dengan pendapat Chatterjee et al (2001) bahwa selama penyimpanan semen beku pada nitrogen cair akan terjadi kerusakan dan kematian spermatozoa serta akan mengurangi fertilitas nya. Straw yang digunakan dalam penelitian yang sudah dilakukan penyimpanan kurang lebih selama 8-10 tahun.

\section{Conception Rate (CR)}

Berdasarkan Tabel 1. diatas menunjukkan bahwa persentase $\mathrm{CR}$ dari IB semen beku non sexing lebih baik dari pada IB semen beku sexing yaitu 79,22\% dan 57,14\%. Hasil penelitian IB menggunakan semen beku non sexing dan semen beku sexing menggunakan metode SGDP memiliki nilai CR berturut-turut yaitu sebesar 44,44\% dan 25,92\% (Wahyudi, dkk., 2014); 74,07\% dan $55,56 \%$ (Fernanda, Susilawati dan Isnaini, 2014); 55,10\% dan 65,31\% (Yekti, dkk., 2018). Kemampuan sapi betina untuk bunting pada inseminasi pertama dipengaruhi oleh variasi lingkungan diantaranya keadaan kandang dan suhu kandang (Nuryadi dan Wahyuningsih, 2011).

Lokasi berpengaruh terhadap perbedaan iklim dan cuaca serta persediaan pakan yang akan mempengaruhi kinerja reproduksi ternak. Kondisi lokasi penelitian ini yaitu Kecamatan Palang bersuhu panas, sehingga akan membuat ternak stress dan saat musim kemarau 
persediaan pakan berkurang. Menurut, Yekti, dkk., (2017) menyatakan bahwa sapi persilangan antara PO dengan Simental atau Limousin akan mudah stress pada kondisi panas akibat tingginya kadar lignin dalam pakan yang akan menyebabkan berahi tenang (silent heat) dan anovular.

Pakan merupakan sumber terbesar kolesterol, karena pakan mengandung 3 pokok kandungan nutrisi yakni lemak, karbohidrat dan protein. Lemak tersebut penyumbang terbesar yang mana lemak akan didegradasi oleh mikroba rumen menjadi asam lemak dan protein yang selanjutnya akan disintesis menjadi kolesterol. Karakteristik peternak di lokasi penelitian untuk sumber pakan bergantung

Tabel 2. Kecukupan Kebutuhan Nutrisi

\begin{tabular}{lcc}
\hline Evaluasi Kecukupan Nutrisi (kg/ekor/hari) & $\begin{array}{c}\text { Non Sexing } \\
\text { (Rata-Rata } \pm \text { SD) }\end{array}$ & $\begin{array}{c}\text { Sexing } \\
\text { (Rata-Rata } \pm \text { SD) }\end{array}$ \\
\hline Evaluasi Kecukupan Konsumsi BK & & \\
\hline Konsumsi BK & $6,64 \pm 3,82$ & $7,07 \pm 4,54$ \\
Kebutuhan BK & $7,57 \pm 0,00$ & $7,57 \pm 0,00$ \\
Kecukupan Konsumsi BK & $-0,93 \pm 0,00$ & $-0,50 \pm 0,00$ \\
\hline Evaluasi Kecukupan Konsumsi PK & & \\
\hline Konsumsi PK & $0,36 \pm 0,21$ & $0,42 \pm 0,30$ \\
Kebutuhan PK & $0,54 \pm 0,00$ & $0,54 \pm 0,00$ \\
Kecukupan Konsumsi PK & $-0,18 \pm 0,00$ & $-0,12 \pm 0,00$ \\
\hline Evaluasi Kecukupan Konsumsi TDN & & \\
\hline Konsumsi TDN & $2,66 \pm 1,42$ & $2,91 \pm 1,78$ \\
Kebutuhan TDN & $3,72 \pm 0,00$ & $3,72 \pm 0,00$ \\
Kecukupan Konsumsi TDN & $-1,06 \pm 0,00$ & $-0,81 \pm 0,00$ \\
\hline Keteranga
\end{tabular}

pada alam dan jarang peternak memilki lahan khusus penanaman rumput. Pada saat penelitian berlangsung terjadi kekurangan pakan akibat musim kemarau yang menyebabkan rendahnya kualitas dan kuantitas produksi pakan sehingga hal tersebut memungkinkan terjadinya berahi ulang pasca IB, karena kekurangan asupan lemak sebagai sumber hormon steroid. Hormon steroid merupakan golongan hormon yang bahan dasarnya adalah kolesterol yang dihasilkan oleh ovarium bagi sapi betina (Yekti, dkk., 2017). Kecukupan kebutuhan nutrisi pakan pada lokasi penelitian dapat dilihat pada tabel berikut ini.

Keterangan: tanda negatif (-) pada kolom dan baris menunjukkan kekurangan nutrisi. 
Berdasarkan Tabel 2. di atas menunjukkan bahwa masing-masing akseptor IB non sexing dan akseptor IB sexing masih dibawah standart kecukupan nutrisi untuk induk sapi betina. Kecukupan konsumsi BK kurang sebesar 0,93 $\pm 0,00$ $\mathrm{kg} / \mathrm{ekor} / \mathrm{hari}$ dan $0,50 \pm 0,00 \mathrm{~kg} / \mathrm{ekor} / \mathrm{hari}$. Kecukupan konsumsi PK kurang sebesar $0,18 \pm 0,00 \mathrm{~kg} / \mathrm{ekor} /$ hari dan $0,12 \pm 0,00$ $\mathrm{kg} / \mathrm{ekor} / \mathrm{hari}$. Kecukupan konsumsi TDN kurang sebesar $1,06 \pm 0,00 \mathrm{~kg} / \mathrm{ekor} / \mathrm{hari}$ dan $0,81 \pm 0,00 \mathrm{~kg} / \mathrm{ekor} /$ hari. Menurut, NRC 2001 menyatakan bahwa standark kecukupan nutrisi untuk induk sapi betina yaitu standart kecukupan konsumsi BK sebesar 7,57 kg/ekor/hari, standart kecukupan konsumsi PK sebesar 0,54 $\mathrm{kg}$ /ekor/hari dan standart kecukupan konsumsi TDN sebesar 3,72 kg/ekor/hari.

Selain kekurangan produksi pakan pada musim kemarau yang menyebabkan kematian embrio sebelum implantasi adalah adanya induk yang menyusui pedet nya. Induk yang menyusui akan memproduksi hormon oksitosis akibat adanya rangsangan pada puting yang akan merangsang hipothalamus untuk menggretak hipofisa posterior yang akan mengeluarkan hormon oksitosin. Adanya hormon oksitosin menyebabkan kontraksi pada uterus. Berdasarkan pendapat, Aji, dkk., (2017) bahwa proses menyusui akan menyebakan tidak terjadinya implantasi. Kematian embrio dini banyak terjadi pada ternak - ternak yang sedang menyusui dikarenakan oleh terhambatnya proses implantasi di endometrium dikarenakan rendahnya hormon steroid dan dihasilkannya oksitosin (Jousan, Drost and Hansen, 2005).

\section{KESIMPULAN DAN SARAN Kesimpulan}

Tingkat keberhasilan IB semen beku non sexing lebih tinggi daripada semen beku sexing menggunakan metode SGDP pada Sapi Persilangan Ongole yaitu nilai Non Return Rate (NRR) sebesar 88,31\% dan $76,62 \%$, persentase kebuntingan sebesar 84,42 \% dan 75,33\%, Conception Rate (CR) sebesar 79,22 \% dan 57,14\%.

\section{Saran}

Perlu dilakukan evaluasi keberhasilan IB pada musim yang berbeda untuk diketahui perbedaan nya dan ketersediaan yang melimpah pakan pada musim penghujan.

\section{UCAPAN TERIMAKASIH}

Terimakasih kepada Bank Indonesia (BI) sebagai penyandang dana penelitian.

\section{DAFTAR PUSTAKA}

Aji, R., Panjono, A. Agus, B. P. Widyobroto, T. Hartatik, I. G. S. Budisatria, Ismaya dan S. Bintara. 2017. Kinerja Reproduksi Sapi Betina Sumba Ongole yang Di Inseminasi dengan Semen Beku Sapi Jantan Belgian Blue. Buletin Peternakan, 41(4), 379 - 384.

Arifiantini, R. I., B. Purwantara, T. L. Yusuf, D. Sajuthi dan Amorzi. 2010. Angka Konsepsi Hasil Inseminasi Semen Cair Versus Semen Beku pada Kuda Yang disinkronisasi Estrus dan Ovulasi. Media Peternakan, 33(1), 3.

Bhalakiya, N., N. Haque, D. Patel, A. Chaudhari, G. Patel, M. Madhavatar, P. Patel, S. A. Hosein and R. Kumar. 2018. Sperm Sexing an Its Application in Livestock Sector. Int. J. Curr. Miceobiol. App. Sci., 7, 259-272.

DOI:https://www.researchgate.net/ publication/324645016

Boro, P., B. C. Naha, A. Madkar and C. Prakash. 2016. Sexing of Semen Bull: A Mini Review. International Journal of Applied Research, 2(4), 460-462.

DOI:10.14737/journal.aavs/2014/2. 4.226.232

Chatterjee, S., E. R. Smith, K. Hanada, V. L. Stevens and S. Mayor. 2001. GPI Anchoring Leads to 
Sphingolipid-Dependent Retention Of Endocytoced Proteins In The Recycling Endosomal Compartment. The EMBO Journal, 20(7), 1583-1592.

DOI: $10.1093 / \mathrm{emboj} / 20.7 .1583$

Fernanda, M. T., T. Susilawati dan N. Isnaini. 2014. Keberhasilan IB menggunakan Semen Beku Sexing dengan Metode Sentrifugasi Gradien Densitas Percoll (SGDP) pada Sapi Peranakan Ongole (PO). Jurnal Ilmu-Ilmu Peternakan, 24(3), 1-8.

Gunawan, M., E. M. Kaiin, Dan S. Said. 2015. Aplikasi Inseminasi Buatan dengan Sperma Sexing dalam Meningkatkan Produktivitas Sapi di Peternakan Rakyat. Pros. Sem. Nas. Masy. Biodiv. Indon., 1(1), 93-96.

Hafez, E. S. E and B. Hafez. 2008. X and Y Chromosome Bearing Spermatozoa. In: Reproduction in Farm Animals. Edited by B. Hafez and E. S. E. Hafez - 7th ed. Lippincott. Williams \& Wilkins. USA: 390393.

Harsojuwono, B. A., I. W. Arnata dan G. A. K. D. Puspawati. 2011. Rancangan Percobaan. Teori, Aplikasi SPSS dan Excel. Lintas Kata Publishing. Malang. ISBN: 978-602-99853-1-3.

Jousan, F. D., M. Drost and P. J. Hansen. 2005. Factors Associated With Early and Mid-To-Late Fetal Loss In Lactating An Non Lactating Holstein Cattle In a Hot Climate. $J$. Anim. Sci,. 83, 1017 - 1022. DOI: $10.2527 / 2005.8351017 \mathrm{x}$

Kanesharatnam, N., T. Eswaramohan and K. Balasubramaniam. 2012. Fractionation of $\mathrm{X}$ and $\mathrm{Y}$ Chromosome-Bearing Bovine Spermatozoa through Sugar Gradients for Sex Predetermintion in Dairy Cattle. International Journal of Bioscience, Biochemistry and Bioinformatics, 2(3), 203-206.

DOI: 10.7763/IJBBB.2012.V2.101

Kusumawati, E.D, N. Isnaini, A.P.A Yekti, M. Lutfi, L. Affandy, D. Pamungkas, Kuswati, Ridhowi, H. Sudarwati, T. Susilawati, S. Rahayu. 2017. The Spermatozoa Quality of Sexed Semen on Filial Ongole Bull Using Percoll Density Gradient Centrifugation Method. Asian Jr. of Microbiol. Biotech. Env. Sci., 19(1), 189-199. DOI: https://www.researchgate.net/publi cation $/ 318583448$

NRC. 2001. Nutrient Requirements of Beef Cattle: Seventh Revised Edition: Update 2000. Subcommittee on Beef Cattle Nutrition. Committee on Animal Nutrition. National Research Council.

Nuryadi dan S. Wahyuningsih. 2011. Penampilan Repruduksi Sapi Peranakan Ongole dan Sapi Peranakan Limousin di Kabupaten Malang. Jurnal Ternak Tropika, 12(1), 76-81.

Setiyani, D. S., A. P. A. Yekti, Kuswati dan T. Susilawati. 2018. Keberhasilan Inseminasi Buatan Menggunakan Semen Sexing Beku Pada Sapi Persilangan Ongole. Jurnal Ilmu-Ilmu Peternakan, 28(3), 259-264.

Sianturi, R. G., P. Situmorang, E. Triwulaningsih dan D. A. Kusumaningrum. 2004. Pengaruh Isobutil Metilixantina (IMX) dan Waktu Pemisahan terhadap Kualitas dan Efektifitas Pemisahan Spermatozoa dengan Metode Kolom Albumin Putih Telur. Jurnal Ilmu Ternak dan Veteriner, 9, 246-251. 
Susilawati, T. 2005. Tingkat Keberhasilan Kebuntingan dan Ketepatan Jenis Kelamin Hasil Inseminasi Buatan Menggunakan Semen Beku Sexing pada Sapi Peranakan Ongole. Animal Production, 7(3), 161-167. . 2011. Spermatology. UB Press. Malang. ISBN: 978-6028960-04-5.

2014. Sexing Spermatozoa. Hasil Penelitian Laboratorium dan Aplikasi Pada Sapi dan Kambing. UB Press. Malang. ISBN: 978-602203-711-8

Susilawati, T., S. Rahayu, S. Udrayana, H. Sudarwati and E. Nugroho. 2014. Effect of Different Centrifugation duration on Simmental Bull Sperm Qualityand Membrane Status after Sexing, Cooling and Freezing Processes. American - Eurasian Journal of Sustainable Agriculture, 8(7), 28-34.

DOI:https://www.researchgate.net/ publication/279524909

Varotto, A., R. Finocchiaro, J. Kaam, M. Marusi and M. Cassandro. 2016. Analysis of Non Return Rate In Italian Holsteun Friesien Bulls. Acta Agriiculturue Slovenica, 5, 94-98.

DOI:http://aas.bf.unilj.si/zootehnik a/supl/5-2016/PDF/5-2016-9498.pdf

Wahyudi, L., Susilawati, T. dan Isnaini, N. 2014. Tampilan Reproduksi Hasil Inseminasi Buatan Menggunakan Semen Beku Hasil Sexing Pada Sapi Persilangan Ongole Pada Peternakan Rakyat. Jurnal Ternak Tropika, 15(1), 80-88.

Widayati, D. T., B. Sugito, T. W. Pangestiningsih, D. L. Kusindarta dan Jaswadi. 2013. Injeksi Kultur Embrio Supernatan dalam Uterus Untuk Meningkatkan Angka Implasntasi Embrio Pada Mencit.
Jurnal Kedoketeran Hewan, 7(2), $155-159$.

Yekti, A. P. A., T. Susilawati, M. N. Ihsan dan S. Wahjuningsih. 2017. Fisiologi Reproduksi Ternak (Dasar Manajemen Reproduksi). UB Press. Malang. ISBN: 978-602432-245-8.

Yekti, A.P.A, E.D. Kusumawati, Kuswati, H. Sudarwati, N. Isnaini and T. Susilawati. 2018. Successfull of Artificial Insemination by Using Chilled Semen Brahman Cross Cows. Advances in Health Science Research (AHSR) $5: 221-226 \quad 1 \mathrm{st}$ International Conference in one Health (ICOH 2017). DOI:https://doi.org/10.2991/icoh$\underline{17.2018 .43}$ 